\title{
Article
}

\section{Comparing endocrown restorations on permanent molars and premolars: a systematic review and meta-analysis}

Thomas, Rose Mary, Kelly, Aengus, Tagiyeva, Nara and Kanagasingam, Shalini

Available at http://clok.uclan.ac.uk/35731/

Thomas, Rose Mary, Kelly, Aengus, Tagiyeva, Nara and Kanagasingam, Shalini (2020) Comparing endocrown restorations on permanent molars and premolars: a systematic review and meta-analysis. British Dental Journal . ISSN 0007-0610

It is advisable to refer to the publisher's version if you intend to cite from the work. http://dx.doi.org/10.1038/s41415-020-2279-y

For more information about UCLan's research in this area go to http://www.uclan.ac.uk/researchgroups/ and search for <name of research Group>.

For information about Research generally at UCLan please go to http://www.uclan.ac.uk/research/

All outputs in CLoK are protected by Intellectual Property Rights law, including Copyright law. Copyright, IPR and Moral Rights for the works on this site are retained by the individual authors and/or other copyright owners. Terms and conditions for use of this material are defined in the policies page. 


\section{Comparing endocrown restorations on permanent molars and premolars: a systematic review and meta-analysis}

\section{Abstract}

Objectives: The objective of this systematic review was to evaluate the success of endocrown restorations on molars in comparison with endocrown restorations on premolars.

Registration number: The methodology for this review is registered with the Prospero database (CRD42019149543).

Data sources: MEDLINE, EMBASE, Dentistry and Oral Sciences source and The Cochrane CENTRAL were searched through January 2020 supplemented with hand searching of additional relevant journals.

Data selection and Data extraction: Two independent reviewers screened studies against predefined inclusion criteria and extracted data.

Data analysis: Narrative analysis was carried out and random effects meta-analysis was performed where possible.

Results: Out of the selected eight studies reported success rate of endocrown restoration in molars varied from $72.7 \%$ to $99.57 \%$ and in premolars ranged from $68.75 \%$ to $100 \%$ with a follow-up range of 3 to 19 years. The pooled odds ratio and $95 \%$ confidence intervals for failure rates in molars compared to premolars in four studies selected for meta-analysis were 1.096 (95\% Cl:0.280, 4.292).

Conclusions: These findings showed similar success rates, and no difference in the rate of endocrown failures between molars and premolars, thus suggesting that premolars may be considered suitable candidates for endocrowns. However, the findings should be interpreted with caution due to methodological limitations of the included studies. Further better quality and specifically designed controlled trials directly comparing the clinical performance of endocrowns on molars and premolars are required. 


\section{Introduction}

Restoration of endodontically treated teeth has always been a challenging topic for dentists as complications may ultimately result in tooth loss if the correct restorative decision is not made. Endodontically treated teeth sustain extensive tooth structure loss, ${ }^{1,2}$ weakening due to factors such as loss of structural integrity, ${ }^{3}$ dentine aging, ${ }^{4}$ reduced proprioception ${ }^{5}$ and to a small extent dentine alteration due to endodontic medicaments. ${ }^{6}$ Evidence suggests that restorations enhancing the structural integrity of these teeth increase their long term prognosis. ${ }^{7,8,9}$

Restoration of endodontically treated teeth with extensive tooth structure loss is particularly demanding as there are numerous choices of restorative materials and restorations, with limited guidance on the best approaches in different circumstances. Posterior teeth are associated with a greater risk of fracture due to exposure to greater occlusal loads which may also further compromise coronal retention. The predominant reason for extraction of endodontically treated teeth has been found to be due to prosthetic reasons. $^{10}$

With advances in adhesive dentistry, a more conservative approach to restoring endodontically treated teeth has been proposed utilising endocrowns. Endocrowns were described by Bindl \& Mormann in $1999^{11}$ as adhesive endodontic crowns for the restoration of root treated posterior teeth with complete loss of coronal hard tissue. Gulabivala \& $\mathrm{Ng}, 2019^{12}$ defined endocrowns as monolithic composite or ceramic endocrowns which incorporates a dowel extension into the pulp chamber for retention (refer Figure 1, Figure 2). Similarly, Fages \& Bennasar in $2013^{13}$ describes endocrown with a retention cavity into the pulp chamber without involving the root canals and a circular equi-gingival or supra-gingival butt margin in an attempt to preserve enamel for better retention and, which is then bonded using an adhesive technique. The central retention cavity should have a minimum of $3 \mathrm{~mm}$ depth and the cervical margin width of at least $2 \mathrm{~mm}$ which are essential for both macro and micro mechanical retention. ${ }^{13}$ It is indicated in extensively damaged clinical crowns, reduced inter-occlusal clearance and in teeth with short, divergent roots. The advantages include ease of preparation, minimal chair time, low cost, aesthetic properties $^{14}$ and fracture resistance. ${ }^{15}$

\section{Figure 1: Diagrammatic representation of Endocrown}

\section{Figure 2: Endocrown- Clinical case}

Legend: A- Endocrown preparation on LR6, B- Laboratory fabricated endocrown, C- Endocrown cemented on LR6 
Ceramic or resin composite materials for endocrowns can be used to create a 'monoblock' within the tooth which reduces the number of adhesive interfaces, thereby decreasing the risk of failure associated with these interfaces. ${ }^{14}$ Endocrown has a preparation design which favors preservation of tooth structure ${ }^{16}$ thereby avoiding the need for post preparation into the root canals which has been associated with higher risk of vertical root fractures and root perforation.

A systematic review by Sedrez-Porto et al. $2016,{ }^{17}$ suggested that endocrowns could perform similarly or better than conventional treatments such as post retained crowns, direct composite restorations, inlays and onlays. Another systematic review by Govare \& Contrepois $2020^{18}$ recommended endocrowns as a reliable alternative to post retained restorations in molars and recommended that further clinical studies are required for the use of endocrowns on premolars. Bindl et al. ${ }^{19}$ queried the suitability of endocrowns on premolars due to the smaller dimensions of the pulp chamber space which decreases the bonding surface area. ${ }^{2,14}$ Given the lack of evidence, the aim of this review is to evaluate and compare the success rates of endocrown restorations on permanent molars to endocrown restorations on permanent premolars.

\section{Materials and Methods}

This systematic review was carried out in accordance with the Preferred Reporting Items for Systematic Reviews and Meta-analyses (PRISMA) guidelines. ${ }^{20}$ This study was carried out at the University of Central Lancashire, United Kingdom and was registered with the Prospero database (CRD42019149543).

\section{Eligibility criteria}

The inclusion and exclusion criteria were developed using the population, intervention, comparator and outcome (PICO) framework.

Population: Endodontically-treated permanent molars or premolars

Intervention/ exposure: Endocrown restoration of endodontically-treated permanent molars.

Comparator: Endocrown restoration of endodontically-treated permanent premolars.

Outcome: Success of the restoration.

Settings: Studies conducted in primary or secondary care settings performed by individual dentists or group of dentists or dental students will be included. 
Randomised and quasi randomised control trials, clinical before-after trials and observational designs (prospective and retrospective cohorts, case-control and cross-sectional studies) reporting endocrown restoration of root filled permanent molars or premolars with a minimum of three year follow up were included. We excluded case reports, case series, conference abstracts, letters, editorials and in vitro studies. We also excluded studies with a follow-up period of less than three years. This three-year minimum was based on recommendations from a Cochrane systematic review ${ }^{21}$ for assessing clinical studies. Studies reporting endocrown restoration of anterior teeth were excluded, as were primary studies with unclear or incomplete reporting and where attempted contact with the authors did not yield additional data. No limitation in language or year of publication were applied.

\section{Analysis of subgroups or subsets}

A series of subgroups were identified for analysis, and defined by:

- Amount of tooth structure

- Materials used for the fabrication of the restoration

- Materials used for bonding the restoration

\section{Search strategy and data management and selection}

We undertook searches of four electronic databases (MEDLINE, EMBASE, Dentistry and Oral Sciences source and The Cochrane CENTRAL). The original searches were done from inception to February 2019 (Figure: 3 ) and were updated in all databases on the 22 of January 2020 , so as to identify potentially eligible recent studies following the last search.

The following search string was used in MEDLINE and tailored accordingly for other databases: [Endocrown* OR Endo-crown* OR (MH "crowns") OR (MH "Dental Restoration, Permanent") OR Ceramic restoration* OR (MH"Ceramics") OR Endodontic restoration* OR cerec OR "milled crown" OR (MH"Computer-Aided Design") OR CAD-CAM crown OR computer aided design OR post endodontic restoration* OR crowns OR Dental restoration] AND [(MH "Dental Restoration Failure") OR Survival OR (MH "Survival") OR (MH "Survival rate") OR Success OR Retention OR (MH "Dental Debonding") OR Debond OR (MH"Tooth Extraction") OR Fracture OR (MH"Longevity") OR Tooth extraction OR Longevity OR Dental Restoration Failure] AND [(MH "Bicuspid") OR Premolar* OR (MH"molar") OR molar* OR Bicuspid). The full search strategies for each data base with date searched are presented in the online supplementary material. This search was supplemented by the search for unpublished and in progress trials in the key internet-based databases: www.ClinicalTrials.gov.uk, www.controlledtrials.com and Google Scholar web search engine. Experts in the field were successfully contacted to identify any additional studies that were not revealed by the electronic search. Hand searching of additional relevant 
journals, Journal of Prosthetic Dentistry, Journal of Endodontics, British Dental Journal, and Dental Update were completed. Forward citation and the bibliographies of eligible studies were reviewed.

The references identified through the search in each database and other sources were exported into reference management software Refworks. ${ }^{22}$ After duplicates were eliminated, the title and abstracts of studies were screened for eligibility. Irrelevant studies were excluded and the full text papers of potentially eligible studies were screened against inclusion and exclusion criteria. The study selection was carried out by two reviewers (RT \& AK) independently and any conflicts in opinion were resolved by discussion and through moderation with a third reviewer (SK).

The original intention was to review direct comparisons of molar and premolar endocrowns but we had to alter the inclusion criteria based on the available literature. Although a number of studies included molars and premolars, none of them made a direct, substantive comparison. Hence we included studies with either a comparative or non-comparative prospective research design. All included studies reported survival/failure rates for at least 3 years, and presented data on endocrowns placed on molars, on premolars, or on both molars and premolars. Where papers reported the same study with different follow up time, the studies with longer follow up period were selected.

\section{Data extraction}

Data extraction was carried out independently by two reviewers (SK \& RT) using a specially designed and pre-piloted data extraction proforma. If data were missing or unclear, the authors were contacted by email to obtain information. Authors of three of the included studies ${ }^{23,24,25}$ responded by email to provide additional relevant information regarding the intervention which was required for data extraction. Extracted data included: patients demographics, intervention details, reported outcomes, failures, reason for failures, Clinical assessment (amount of remaining tooth structure, presence of adjacent teeth, abutment of Fixed partial denture/Removable partial denture, endodontic assessment, periodontal assessment, occlusal and parafunctional assessments), Materials (fabrication of restoration/device, bonding material/process). The extracted data were compared and any differences were discussed and resolved.

\section{Outcome criteria}

Success of the restoration was the primary outcome in this systematic review. The restorations were considered to be successful if they presented without any aspects of failure such as any symptoms or complications, repairs or debonds, based on clinical and/or radiographic examination. 


\section{Assessment of Methodological quality}

Two reviewers (RT, SK) critically appraised the included studies with a third reviewer (AK) as a moderator, using the Effective Public Health Practice Project (EPHPP) tool. This tool provides a standardised means of assessing study quality by providing overall methodological rating of strong, moderate or weak. ${ }^{26}$

\section{Data Analysis}

The meta-analysis was carried out to compare the outcome in molars vs premolars using a randomeffects model in Comprehensive Meta-Analysis (version 3). Data were analysed according to the intention to treat principle, using the total number of patients as the denominator. Results were expressed as odds ratios (ORs) with 95\% confidence intervals $(\mathrm{Cl})$. Heterogeneity was assessed with the $\mathrm{I}^{2}$ statistic and substantial heterogeneity assumed if $\mathrm{I}^{2}$ was greater than $40 \%$. Sensitivity analyses was performed including only studies with follow up longer that seven years. A funnel plot was not presented as the number of studies included in the meta-analyses was less than 10. For outcomes for which it was not possible to produce a meta-analysis, we narratively synthesized data.

\section{Results}

\section{Search Strategy}

The electronic literature search resulted in 4015 studies from EMBASE, 3927 studies from MEDLINE, 471 studies from The Cochrane Library, and 347 studies from Dentistry \& Oral Sciences databases making a total of 8760 studies. The study selection process is presented using a PRISMA flowchart (Figure 3). Finally, a total of eight studies were included in this review; 6 prospective cohorts ${ }^{19,23,24,27,28,29}$ and two retrospective cohorts. ${ }^{25,30}$ The latest search to update (with publication year limitation 2019 to 2020) resulted in 311 studies from EMBASE, 478 studies from MEDLINE, 72 studies from The Cochrane Library, and 95 studies from Dentistry \& Oral Sciences databases but the latest search results did not yield any relevant studies.

Figure 3: Identification, Screening and Inclusion of studies formatted in a PRISMA flow chart 


\section{Descriptive analysis}

The Table of Study Characteristics (Table 1) shows the eight studies included in the present review, published between 2005 and 2017. Four of the studies ${ }^{19,23,24,28}$ included endocrowns as one of the interventions involving posterior teeth, so the data from these studies regarding molar endocrowns and premolar endocrowns were extracted from the pool of data. All of the eight selected studies $^{19,23,24,25,27,28,29,30}$ included molar endocrowns and four of these studies ${ }^{19,23,25,30}$ included both molar and premolar endocrowns. The follow up period of the studies ranged from 3 years up to 19 years. The data extraction table is presented in the online supplementary material.

The outcome measures used in the 8 selected studies were not consistent. Five of the studies ${ }^{19,23,27,28,29}$ employed modified United States Public Health Service (USPHS) Criteria for the direct clinical evaluation of the restoration, and others used a range of measures including clinical periodontal markers, adhesive failures or debonds, fracture of the restoration, vertical root fracture, secondary caries, and endodontic failure. In this review among the USPHS criteria, the criteria for " secondary caries" and "fracture" were considered as a failure of the restoration, as the other criteria (color match, marginal discoloration, marginal integrity, anatomic contour and surface texture) would be more appropriate in the assessment of an anterior tooth restoration.

\section{Table 1: The Table of Study Characteristics}

Table 2 Summarises the clinical technique. The amount of tooth structure in all of the studies conformed to the Dental Practicality Index- Level 2 as described by Dawood and Patel $2017 .{ }^{31}$ Ceramic was the material of choice in five of the studies, ${ }^{19,23,24,28,29}$ Botto et al. ${ }^{25}$ used ceramic, gold alloy and indirect composite materials, Belleflamme et al. ${ }^{30}$ used ceramic, hybrid ceramic and indirect composite while Liu \& Ma $2008{ }^{27}$ used gold, platinum and nickel chromium alloy for the fabrication of endocrowns. There were also variations in the luting cements used, ie. dual cure luting cement was used in five of the studies, $^{23,25,28,29,30}$ self-cure luting cement was used in two of the studies ${ }^{24,27}$ while light cured luting cement was used in Bindl et al. ${ }^{19}$

\section{Table 2: Summary of Clinical Technique}

Table 3 details the Summary of findings split into studies on molar endocrowns and premolar endocrowns, including the number of failures, loss to follow up, follow up period and reason for failure. 
The sample size of premolars ranged from $2^{25}$ to $41^{30}$ and the sample size for molars ranged from $9^{25}$ to $235^{24}$. The outcome measures also varied across the studies. The reported success rate of endocrown restorations were similar: molars varied from $72.73 \%{ }^{28}$ to $99.57 \%{ }^{24}$ and premolars ranged from $68.75 \%{ }^{19}$ to $100 \%{ }^{25}$ with varied follow-up period. The reported failure rate of endocrown restoration in molars varied from $0.43 \%{ }^{24}$ to $27.27 \%{ }^{28}$ and in premolars ranged from $0 \%{ }^{25}$ to $31.25 \%{ }^{19}$ and the main reason for failure was adhesive failure predominantly reported in Bindl et al. ${ }^{19}$

Table 3: Summary of findings split into studies on molar endocrown and premolar endocrownLegend: $M=$ molars, $P M=$ premolars

\section{Meta-analysis}

Four out of eight included studies reported outcomes on molars and premolars and were selected for meta-analysis. ${ }^{19,23,25,30}$ The results showed no statistically significant difference in the rate of endocrown failures between molars and premolars (OR $1.096(95 \% \mathrm{Cl}: 0.280,4.292)(p=0.895)\left(I^{2}=38.4 \%\right)$ (Figure 4).

Figure 4: Forest plot showing ORs and $95 \% \mathrm{Cl}$ for the difference in failure rates in molars vs premolars (random-effects model)

All studies included in the meta-analysis except for Bindl et al. ${ }^{19}$ had more than seven years follow up and used the same luting cement (dual cured), therefore a subgroup meta-analysis was carried out with these studies only. ${ }^{23,25,30}$ The results also found no statistically significant difference in the rate of endocrown failures between molars and premolars (OR $1.811(95 \% \mathrm{Cl} 0.274,11.968)(p=0.538)$ (Figure 5).

Figure 5: Meta-analysis of failure rates of endocrowns on molars vs premolars in studies with follow up above 7 years (random-effect model).

\section{Quality assessment of the studies}

Quality assessment of the included studies using EPHPP found seven of the included studies ${ }^{19}$, $23,24,25,27,28,30$ to be of weak rating and Ozyoney et al. ${ }^{29}$ to have a moderate rating. The blinding component was rated weak in all the eight studies and the confounder component was weak in the seven studies except for Ozyoney et al. ${ }^{29}$ Table summarising the quality assessment is presented in the online supplementary material. 
This systematic review evaluated the success rate of endocrowns on molars and premolars in clinical studies and found them to be similar: molars varied from $72.73 \%{ }^{28}$ to $99.57 \%{ }^{24}$ and premolars ranged from $68.75 \%{ }^{19}$ to $100 \%{ }^{25}$ with varied follow-up period. The results of a meta-analysis of four studies $^{19,23,25,30}$ found no statistically significant difference in the rate of endocrown failures between molars and premolars. The key finding of this review is that, despite previous evidence, ${ }^{18,19}$ endocrowns on premolars may be as reliable as endocrowns on molars. The most detailed and consistent forms of data found in the reviewed studies related to causes and rates of failure and consequently failure rate was found to be the most significant outcome to report.

The predominant mode of failure was adhesive breakdown or debonds in both molars and premolars, with a total of 5 debonds in the premolar group and 14 debonds in the molar group across the studies. The adhesives used varied across the studies, five of the studies ${ }^{23,25,28,29,30}$ used dual cured luting cement, self-cured luting cement was used by Fages et al. ${ }^{24}$, Liu et al. ${ }^{27}$ used Glass ionomer cement while Bindl et al. ${ }^{19}$ used light cured resin based composite material. Only one study ${ }^{19}$ used light cured composite material for luting. This study contributed the majority of the failures by debonding ( 5 premolar debonds and 9 out of 14 molar debonds) across the eight studies. The authors of the study suggested that the use of light cured resin based composite material may have contributed to the adhesive failure. This may be associated with inefficient curing light penetration resulting in inadequate photo polymerisation of the cement, thus decreasing bond strengths. ${ }^{32,33}$ This is especially critical in the case of endocrowns which incorporate increased thickness as compared to inlay or onlay preparations. Increasing ceramic thickness significantly affects the polymerisation of light cured and dual cured cements. ${ }^{34}$ However, in vitro studies have reported increased time and high intensity halogen lamp over $1200 \mathrm{~mW} / \mathrm{cm}^{2} 35$ or high irradiance LED $\left(1200 \mathrm{~mW} / \mathrm{cm}^{2}\right)^{36}$ can result in adequate polymerisation of both light cured and dual cured resin luting cement. A lower intensity curing light $\left(750 \mathrm{~mW} / \mathrm{cm}^{2}\right)$ was used by Bindl et al. ${ }^{19}$ which may have contributed to the debond failures. Two molar debonds were reported by Otto \& Mormann, ${ }^{23}$ the author attributes the failure to insufficient stabilisation due to minimal pulp chamber extension of less than $2 \mathrm{~mm}$. Endocrowns are contraindicated in teeth with minimal tooth structure or short pulp chamber space. ${ }^{37}$ On balance, debonding of restorations are not considered catastrophic failures (if not accompanied by a fracture) as they can be re-cemented or replacement can be provided but there is an increased risk of coronal leakage resulting in endodontic failure. Preventing coronal leakage into the root canal is crucial and this can be achieved by placing restorative material in the countersunk canal orifices prior to placing the indirect restoration. ${ }^{38,39}$

Fracture of the restoration was another reason for failure. Three of the studies ${ }^{23,29,30}$ reported bulk fractures of which 5 were in molars and 2 in premolars. The fracture of a restoration may be attributed to the material used or due to insufficient management of occlusal stress. Most of the included studies ${ }^{19}$, 
$23,24,25,28,29,30$ used ceramic as the material of choice for endocrowns. Ceramic material has the advantage of stiffness but has minimal elasticity which can result in catastrophic fractures. ${ }^{40}$ Otto \& Mormann, ${ }^{23}$ recommended the use of machinable composite material with a modulus of elasticity close to that of dentine to be a valuable alternative to ceramic endocrown. He explained the debonding of ceramic endocrowns to be due to the high modulus of elasticity of the ceramic which transfers the chewing force to the interface between the luting cement and dentine, resulting in stress at the interface thereby causing debonding of the endocrown restoration. An in vitro study ${ }^{41}$ concluded that CAD/CAM crowns and endocrowns fabricated from millable composites performed superiorly to all ceramic crowns and endocrowns. SEM micrographs in this study revealed dentine cracks in the loaded specimens restored with ceramic crowns whereas no dentine cracks were observed when composite crowns were used for restoration. Internal stress can induce the formation of dentine cracks, which can be interpreted as a sign of early failure. ${ }^{41}$ The use of composite resin onlays have been shown to reduce internal stresses compared to ceramic and gold alloy, which have a higher modulus of elasticity. ${ }^{8}$ Composites also have the additional advantage that it can be adjusted and repaired intraorally, whereas ceramic repair intraorally can only be considered as a temporary option. ${ }^{41}$

There were periodontal failures reported in four of the studies ${ }^{19,25,27,30}$ and all the 7 periodontal failures involved molars. Belleflamme et al. ${ }^{30}$ reported that periodontal failures occurred in patients with general periodontitis. Three of the studies ${ }^{23,27,29}$ mentioned examination of periodontal health to be one of the inclusion criteria which is an important factor to be considered to avoid confounding factors, as periodontal failures may not be a failure of the restoration itself. Assessment of occlusal determinants and presence or absence of parafunctional habits are also key clinical elements which can affect the long term survival of a restoration. ${ }^{42}$ Occlusal assessments were carried out in four of the studies ${ }^{19,23,25,30}$ and parafunctional habits were assessed in four of the studies. ${ }^{24,25,29,30}$ Beier et al. ${ }^{43}$ reported high failure rate of restorations in patients with parafunctional habits and they determined the risk to be 2.3 times greater in patients with bruxism than in patients without bruxism. However, Belleflamme et al. ${ }^{30}$ reported a survival rate of $99 \%$ even in the presence of occlusal risk factors such as bruxism and unfavorable occlusal relationships. Two endodontic failures were reported in molars ${ }^{19,29}$ but only two studies ${ }^{29,30}$ reported endodontic examination and provision of retreatment prior to intervention.

A recent Systematic review on Endocrowns by Govare \& Contrepois $2020^{18}$ included 8 clinical studies and 33 in vitro studies. The failure modes of endocrowns reported were adhesive failures, periodontal failures and fracture of restoration which is consistent with the findings of this systematic review. They reported predominant mode of failures in clinical studies on premolars to be adhesive failures but they also pointed out that the dissatisfying clinical results were in contrast to the in vitro findings. Govare \& Contrepois $2020^{18}$ did not incorporate strict criteria for the follow up period, resulting in the inclusion of four short term studies ${ }^{11,44,45,46}$ with review duration/time period as little as 6 months. ${ }^{46}$ Moreover, meta- 
analysis was not performed and four clinical studies with long-term follow up included in this current systematic review were overlooked by Govare \& Contrepois $2020 .^{18}$

The amount of tooth structure was one of the parameters which was analyzed in this review as it is considered to be the predictor of long term clinical success. ${ }^{37}$ The description of the amount of remaining tooth structure varied across the studies. Hence, a recognized index (Dental Practicality Index or DPI) ${ }^{31,47}$ was used to standardise the manner in which the residual tooth structure was classified. The amount of tooth structure in all the included studies conformed to Level 2 structural integrity of DPI.

There are limitations in the studies identified for review. The reporting of clinical data was inconsistent. The follow up time in the included eight articles varied from 3 years to 19 years, which precluded comparison of outcome at specific time points. The included studies were weak to moderate in methodological quality. Two of the studies were retrospective studies ${ }^{25,30}$ which can generate a high risk of bias. The outcome measurement was carried out by the same operator in three of the studies. ${ }^{23,24,29}$ Independent assessors carried out the outcome measure in four of the studies ${ }^{19,25,28,30}$ but were not blinded.

Four of the studies were carried out in University settings, ${ }^{19,28,29,30}$ three of the studies were carried out in Private practice settings, ${ }^{23,24,25}$ while Liu \& $\mathrm{Ma}^{27}$ has not reported the settings in which the study was carries out.

Regarding the tooth preparation for endocrown three of the included studies did not mention the criteria for tooth preparation. ${ }^{19,28,29}$ Botto et al. ${ }^{25}$ used both butt and chamfer finish margins while Fages et al. ${ }^{24}$ used butt finish margin and Belleflamme et al. ${ }^{30}$ used chamfer finish margins. Tapered pulp chamber extension of the preparation was reported in three of the studies ${ }^{23,24,30}$ while Liu \& Ma ${ }^{27}$ reported box shaped pulp chamber preparation. Otto \& Mormann ${ }^{23}$ and Fages et al. ${ }^{24}$ also reported removal of residual thin walls of the tooth preparation.

The limitations described above should be taken into consideration while interpreting the results and therefore further long term randomised controlled clinical trials are required comparing the effectiveness of endocrowns on premolars and molars, with adequate sample size. An ideal study design would include parallel groups of molars and premolars allowing strict definition of the amount of remaining tooth structure with an index to measure against. Inclusion and exclusion criteria should be well defined in order to limit the confounding factors such as poor oral hygiene, caries risk, periodontal risk, occlusal interference and parafunctional habits. There should be a strict protocol for pre-operative clinical and radiographic assessment, the quality of root fillings should be assessed and revised if not adequate with a follow up of at least 3 years, good allocation concealment, experienced and trained operators and assessors, blinded assessments of follow up evaluation using clinical assessment and periapical radiographs so as to determine the endodontic and restorative outcome of the tooth and restoration. 
The results of the present review provide a counterargument to the perception present in the literature ${ }^{18,19}$ that premolars may not be suitable candidates for endocrown. Emphasis should be made on the importance of strict clinical procedures, including preservation of tooth structure, type of materials and cements with appropriate protocol to improve the clinical success of the restoration. ${ }^{18,25,33}$

\section{Conclusions}

The results from the individual studies and the pooled estimates showed no statistically significant difference in the rate of endocrown failures between molars and premolars. The available evidence suggests that endocrowns on premolars and molars have similar high rates of longevity and that premolars may potentially be considered candidates for endocrown. The results of this review should however, be viewed with caution as there were methodological limitations in the included studies. This review has highlighted the need for larger longer term controlled trials directly comparing the clinical performance of endocrowns on molars and premolars to confirm the findings.

\section{Declaration of interests}

This research did not receive any specific grant from funding agencies in the public, commercial or notfor-profit sectors.

\section{Acknowledgements}

The authors would like to acknowledge, Dr Soh Hui Yuh, Lecturer, Faculty of Dentistry, National University of Malaysia, for the translation of the study in Mandarin.

\section{Conflict of Interest}

The authors deny any conflict of interest related to this study. 


\section{References}

1. Mannocci F, Bertelli E, Sherriff M, Watson TF, Ford TP. Three-year clinical comparison of survival of endodontically treated teeth restored with either full cast coverage or with direct composite restoration. J Prosthet Dent. 2002;88(3):297-301.

2. Elagra, Marwa. Endocrown preparation: Review. International Journal of Applied Dental Sciences 2019; 5(1): 253-256.

3. Belli S, Erdemir A, Yildirim C. Reinforcement effect of polyethylene fibre in root-filled teeth: Comparison of two restoration techniques. Int Endod J. 2006;39(2):136-42.

4. Mireku AS, Romberg E, Fouad AF, Arola D. Vertical fracture of root filled teeth restored with posts: The effects of patient age and dentine thickness. Int Endod J. 2010;43(3):218-25.

5. Randow K, Glantz P. On cantilever loading of vital and non-vital teeth an experimental clinical study. Acta Odontol Scand. 1986;44(5):271-7.

6. Yassen GH, Vail MM, Chu TG, Platt JA. The effect of medicaments used in endodontic regeneration on root fracture and microhardness of radicular dentine. Int Endod $\mathrm{J}$. 2013;46(7):688-95.

7. Schwartz RS, Robbins JW. Post placement and restoration of endodontically treated teeth: A literature review. J Endod. 2004;30(5):289-301.

8. Jiang $\mathrm{W}$, Bo $\mathrm{H}$, Yongchun $\mathrm{G}$, LongXing $\mathrm{N}$. Stress distribution in molars restored with inlays or onlays with or without endodontic treatment: A three-dimensional finite element analysis. J Prosthet Dent. 2010;103(1):6-12.

9. Ng YL, Mann V, Gulabivala K. A prospective study of the factors affecting outcomes of nonsurgical root canal treatment: part 2: tooth survival. Int Endod J. 2011;44:610-625.

10. Olcay K, Ataoglu H, Belli S. Evaluation of Related Factors in the Failure of Endodontically Treated Teeth: A Cross-sectional Study. Journal of Endodontics 2018;44(1):38-45.

11. Bindl A, Mormann WH. Clinical evaluation of adhesively placed cerec endo-crowns after 2 yearspreliminary results. J Adhes Dent. 1999;1:255-66.

12. Gulabivala $\mathrm{K}, \mathrm{Ng} \mathrm{Y}$. Value of root-filled teeth in maintaining a functional dentition for life. $\mathrm{Br}$ Dent J. 2019;226(10):769.

13. Fages M, Bennasar B. The endocrown: A different type of all-ceramic reconstruction for molars. J Can Dent Assoc. 2013;79:d140.

14. Sevimli G, Cengiz S, Oruc MS. Endocrowns. Journal of Istanbul University Faculty of Dentistry. 2015;49(2):57.

15. Chang C, Kuo J, Lin Y, Chang Y. Fracture resistance and failure modes of CEREC endo-crowns and conventional post and core-supported CEREC crowns. Journal of Dental Sciences. 2009;4(3):110-7.

16. Abu-Awwad M. A modern guide in the management of endodontically treated posterior teeth. European Journal of General Dentistry. 2019;8(3):63. 
17. Sedrez-Porto J, da Rosa, Wellington Luiz,de Oliveira, Da Silva AF, Münchow EA, Pereira-Cenci T. Endocrown restorations: A systematic review and meta-analysis. J Dent. 2016;52:8-14.

18. Govare N, Contrepois M. Endocrowns: A systematic review. The Journal of Prosthetic Dentistry. 2020;123(3):411,418.e9.

19. Bindl A, Richter B, Mörmann WH. Survival of ceramic computer-aided design/manufacturing crowns bonded to preparations with reduced macroretention geometry. The International journal of prosthodontics. 2005 May;18(3):219.

20. Moher D, Liberati A, Tetzlaff J, Altman DG. Preferred reporting items for systematic reviews and meta-analyses: The PRISMA statement. Ann Intern Med. 2009;151(4):264-9.

21. Bolla M, Muller-Bolla M, Borg C, Lupi-Pegurier L, Laplanche O, Leforestier E. Root canal posts for the restoration of root filled teeth. Cochrane Database of Systematic Reviews. 2007(1).

22. Reichardt C. Refworks. Public Services Quarterly. 2010;6(4):366-7.

23. Otto T, Mörmann WH. Clinical performance of chairside CAD/CAM feldspathic ceramic posterior shoulder crowns and endocrowns up to 12 years. Int J Comput Dent. 2015;18(2):147-61.

24. Fages M, Raynal J, Tramini P, Cuisinier FJ, Durand J. Chairside computer-aided design/computer-aided manufacture all-ceramic crown and endocrown restorations: A 7-year survival rate study. The International journal of prosthodontics. $2017 \mathrm{Nov} ; 30$ (6):556-560-560.

25. Borgia Botto E, Barón R, Borgia JL. Endocrown: A retrospective patient series study, in a 8 to 19year period. Odontoestomatologia 2016 Nov.

26. Thomas BH, Ciliska D, Dobbins M, Micucci S. A process for systematically reviewing the literature: Providing the research evidence for public health nursing interventions. Worldviews on evidence-based nursing. 2004;1(3):176-84.

27. Liu XH, Ma L. Use of casting inlays with pulp chamber retention to restore extensive damaged crowns of molars. Shanghai kou qiang yi xue= Shanghai journal of stomatology. 2008;17(1):30-2.

28. Roggendorf M.J., Kramer N., Dippold C., Vosen V.E., Naumann M., JablonskiMomeni A., et al. Effect of proximal box elevation with resin composite on marginal quality of resin composite inlays in vitro. J Dent. 2012 December 2012;40(12):1068-73.

29. Ozyoney G, Yan Koğlu F, Tağtekin D, Hayran O. The efficacy of glass-ceramic onlays in the restoration of morphologically compromised and endodontically treated molars. The International journal of prosthodontics. 2013 May;26(3):230-4.

30. Belleflamme MM, Geerts SO, Louwette MM, Grenade CF, Vanheusden AJ, Mainjot AK. No postno core approach to restore severely damaged posterior teeth: An up to 10-year retrospective study of documented endocrown cases. Journal of Dentistry. 2017;63:1-7.

31. Dawood A, Patel S. The dental practicality index-assessing the restorability of teeth. Br Dent J. 2017;222(10):755.

32. Breeding LC, Dixon DL, Caughman WF. The curing potential of light-activated composite resin luting agents. J Prosthet Dent. 1991;65(4):512-8.

33. D’Arcangelo C, Vanini L, Casinelli M, Frascaria M, De Angelis F, Vadini M, et al. Adhesive cementation of indirect composite inlays and onlays: A literature review. Compend Contin Educ Dent. 2015;36(8):570-7. 
34. Kilinc E, Antonson SA, Hardigan PC, Kesercioglu A. The effect of ceramic restoration shade and thickness on the polymerization of light-and dual-cure resin cements. Oper Dent. 2011;36(6):6619.

35. Ozyesil AG, Usumez A, Gunduz B. The efficiency of different light sources to polymerize composite beneath a simulated ceramic restoration. J Prosthet Dent. 2004;91(2):151-7.

36. Gregor L, Bouillaguet S, Onisor I, Ardu S, Krejci I, Rocca GT. Microhardness of light-and dualpolymerizable luting resins polymerized through 7.5-mm-thick endocrowns. J Prosthet Dent. 2014;112(4):942-8.

37. Imen D. "ENDOCROWN": A reliable alternative to restorate RCT molar! - two case reports. Advances in Dentistry \& Oral Health. 2018 Sep 24;9(5).

38. Schwartz RS, Robbins JW. Post placement and restoration of endodontically treated teeth: A literature review. J Endod. 2004;30(5):289-301.

39. Schwartz RS, Fransman R. Adhesive dentistry and endodontics. part 2: Bonding in the root canal system—the promise and the problems: A review. J Endod. 2006;32(12):1125-34.

40. Sedrez-Porto J, MÜNCHOW EA, Valente LL, Cenci MS, Pereira-Cenci T. New material perspective for endocrown restorations: Effects on mechanical performance and fracture behavior. Brazilian oral research. 2019;33.

41. Ramírez-Sebastià $A$, Bortolotto $T$, Roig $M$, Krejci I. Composite vs ceramic computer-aided design/computer-assisted manufacturing crowns in endodontically treated teeth: Analysis of marginal adaptation. Operative dentistry. 2013 Nov;38(6):663-73.

42. Dietschi D, Duc O, Krejci I, Sadan A. Biomechanical considerations for the restoration of endodontically treated teeth: A systematic review of the literature, part II (evaluation of fatigue behavior, interfaces, and in vivo studies). Quintessence Int. 2008;39(2).

43. Beier US, Kapferer I, Dumfahrt $\mathrm{H}$. Clinical long-term evaluation and failure characteristics of 1,335 all-ceramic restorations. Int J Prosthodont. 2012;25(1).

44. Otto T. Computer-aided direct all-ceramic crowns: preliminary 1-year results of a prospective clinical study. Int J Periodontics Restorative Dent 2004;24:446-55.

45. Bernhart J, Bräuning A, Altenburger MJ, Wrbas KT. Cerec3D endocrowns--two-year clinical examination of CAD/CAM crowns for restoring endodontically treated molars. International journal of computerized dentistry. 2010;13(2):141.

46. Decerle N, Bessadet M, Munoz-Sanchez ML, Eschevins C, Veyrune J, Nicolas E. Evaluation of cerec endocrowns: A preliminary cohort study. The European journal of prosthodontics and restorative dentistry. 2014 Jun;22(2):89.

47. Tifooni A, Al-Nuaimi N, Dawood A, Mannocci F, Patel S. Validation of the effectiveness of the dental practicality index in predicting the outcome of root canal retreatments. Int Endod J. 2019. 


\section{Figure 1}

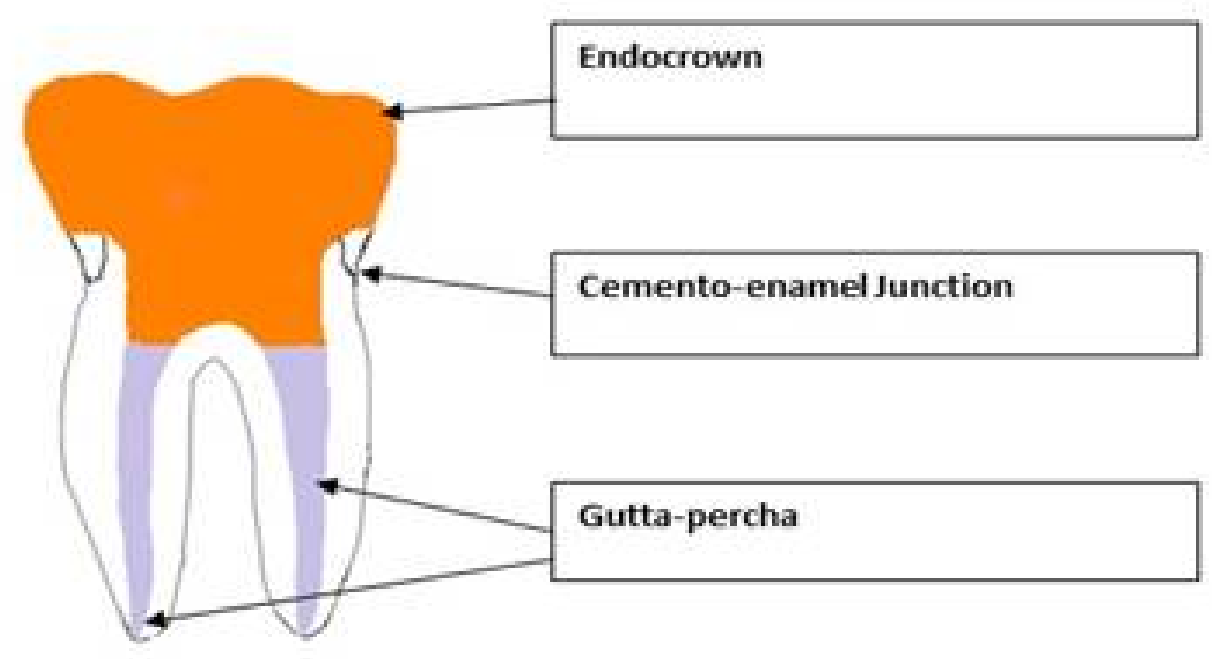


Figure 2

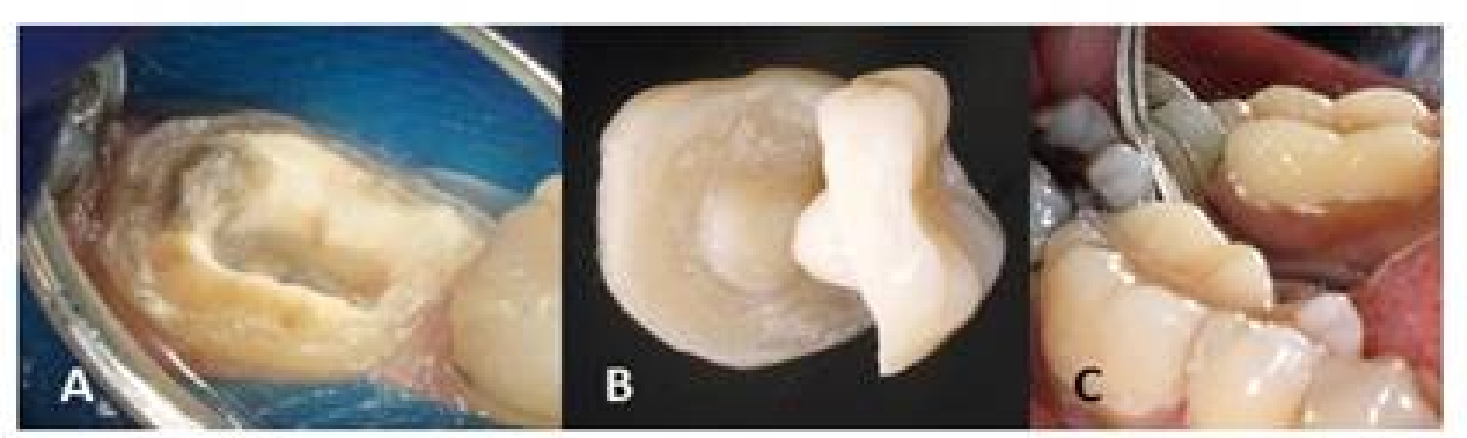




\section{Figure 3}

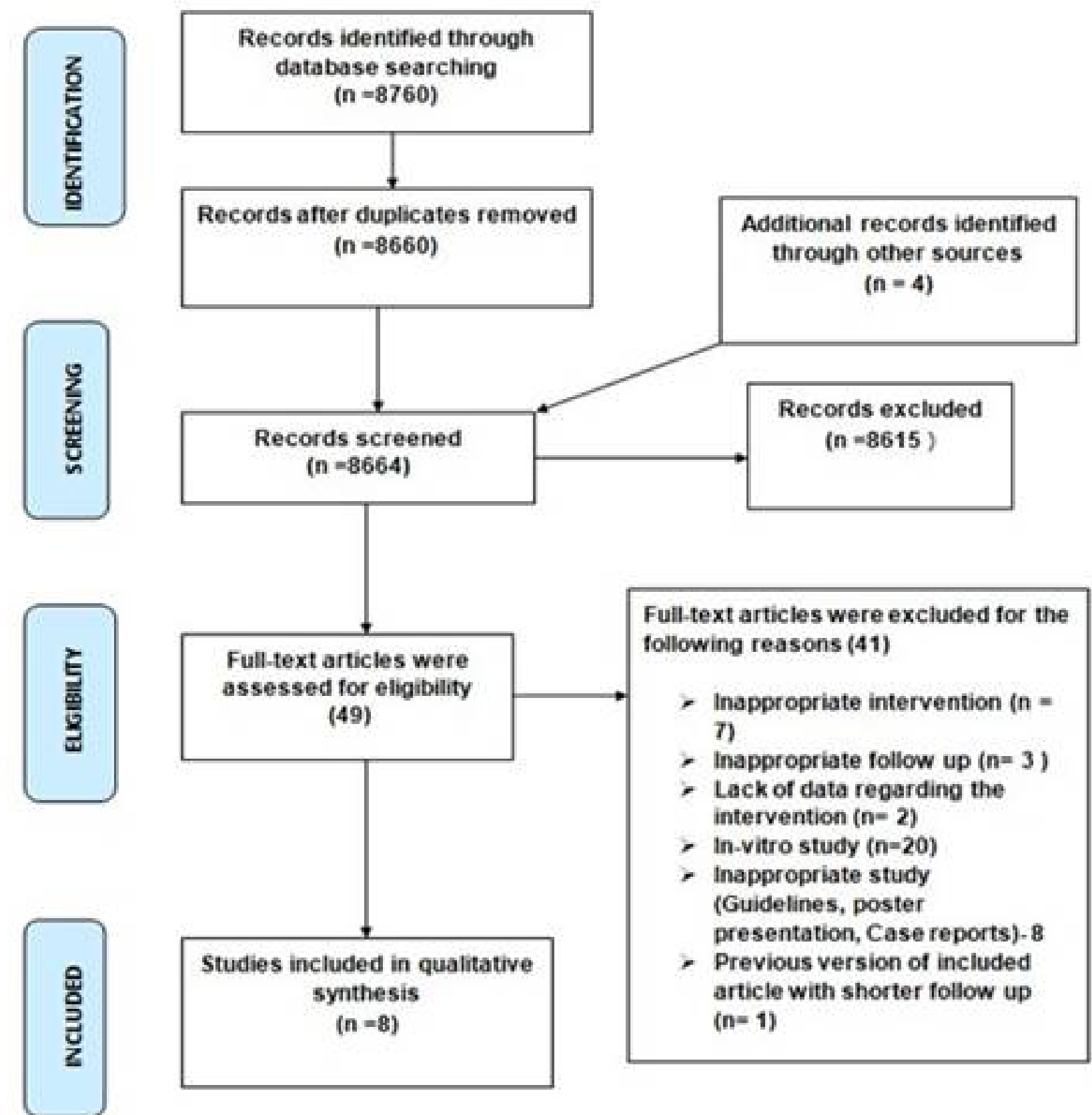




\section{Figure 4}

Study name

Events-Failures / Total

Odds ratio and $95 \% \mathrm{Cl}$

Odds Lower Upper

ratio limit limit Group-A-Molars Group-B-Premolars

$\begin{array}{llllcc}\text { Bindl et a. 2005 } & 0.550 & 0.164 & 1.842 & 14 / 70 & 5 / 16 \\ \text { Otto and Mormann 2015 } & 0.444 & 0.032 & 6.188 & 2 / 20 & 1 / 5 \\ \text { Botto et al 2016 } & 0.882 & 0.027 & 29.146 & 1 / 9 & 0 / 2 \\ \text { Belleflamme 2017 } & 7.660 & 0.930 & 63.088 & 9 / 56 & 1 / 41 \\ & 1.096 & 0.280 & 4.292 & 26 / 155 & 7 / 64\end{array}$

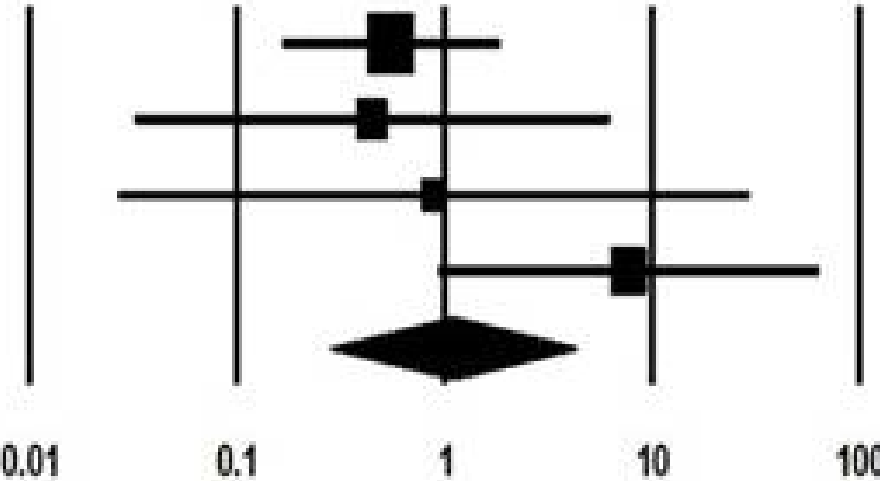

Favours A
Relative

weight

43.13

19.02

12.35

25.50

Heterogeneity: $\tau^{2}=0.744 ; \chi^{2}=4.870, d f=3(p=0.182) ; 1^{2}=38.4 \%$;

Test for overall effect: $Z=0.132$ ( $p$ 0.895) 


\section{Figure 5}

\begin{tabular}{|c|c|c|c|c|c|}
\hline \multirow[t]{2}{*}{ Study name } & \multirow[b]{2}{*}{$\begin{array}{l}\text { Odds } \\
\text { ratio }\end{array}$} & \multirow[b]{2}{*}{$\begin{array}{c}\text { Lower } \\
\text { limit }\end{array}$} & \multirow[b]{2}{*}{$\begin{array}{c}\text { Upper } \\
\text { limit }\end{array}$} & \multicolumn{2}{|c|}{ Failure / Total } \\
\hline & & & & Molar-A & Premolar \\
\hline Otto \& Mormann 20 & 150.444 & 0.032 & 6.188 & $2 / 20$ & $1 / 5$ \\
\hline Botto 2016 & 0.882 & 0.027 & 29.146 & $1 / 9$ & $0 / 2$ \\
\hline Belleflamme 2017 & 7.660 & 0.930 & 63.088 & $9 / 56$ & $1 / 41$ \\
\hline & 1.811 & 0.274 & 11.968 & & \\
\hline
\end{tabular}

Heterogeneity: $\tau^{2}=0.955 ; \chi^{2}=3.018, d f=2(p=0.221) ; 1^{2}=33.7 \%$; Test for overall effect: $Z=0.617$ ( $p 0.538$ )

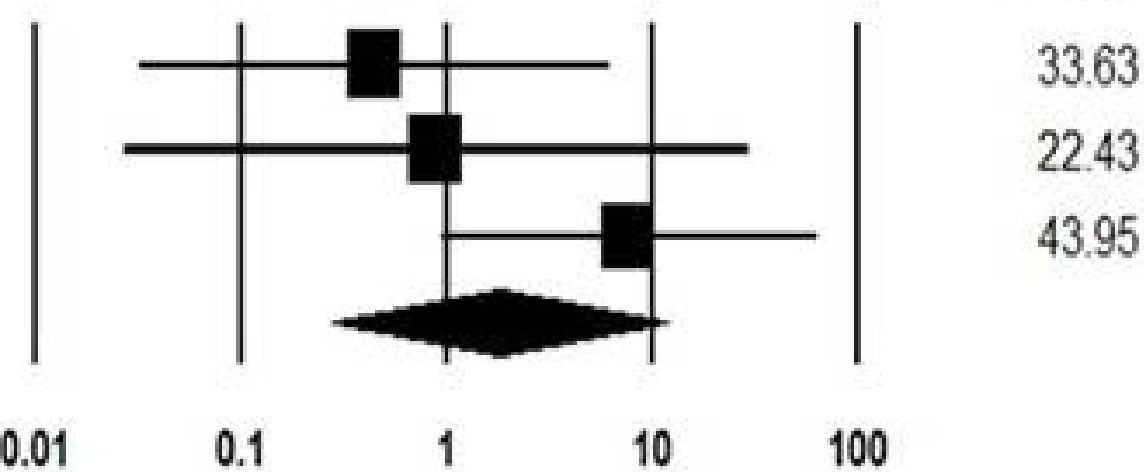

Favours A
Relative weight

33.63

22.43

43.95 
Table 1: The Table of Study Characteristics

\begin{tabular}{|c|c|c|c|c|c|c|c|c|}
\hline $\begin{array}{c}\text { Referenc } \\
\text { e }\end{array}$ & $\begin{array}{l}\text { Study } \\
\text { design }\end{array}$ & $\begin{array}{l}\text { Count } \\
\mathrm{ry} / \mathrm{Re} \\
\text { gion }\end{array}$ & Age (years) & $\begin{array}{l}\text { Participants } \\
\text { and settings }\end{array}$ & $\begin{array}{l}\text { Expertise of the } \\
\text { operator }\end{array}$ & Follow-up period & Outcomes reported & $\begin{array}{l}\text { Methodological } \\
\text { Quality } \\
\text { assessment using } \\
\text { EPHPP- Global } \\
\text { rate }\end{array}$ \\
\hline $\begin{array}{l}\text { Bindl et } \\
\text { al. } \\
2005^{19}\end{array}$ & Prospective & $\begin{array}{l}\text { Switze } \\
\text { rland }\end{array}$ & Age not specified & $\begin{array}{l}136 \text { patients } \\
\text { with } 208 \\
\text { restorations } \\
\text { University } \\
\text { setting }\end{array}$ & not recorded & $\begin{array}{l}3 \text { years or more service time } \\
\text { up to } 7 \text { years } \\
\text { Meantime } 52+/-15 \text { months }\end{array}$ & $\begin{array}{l}\text { - } \text { Debond/Adhesive failure } \\
\text { - } \quad \text { Fracture of ceramic } \\
\text { - } \quad \text { Inter-radicul root fracture } \\
\text { - } \quad \text { Periodontitis } \\
\text { USPHS criteria used for } \\
\text { evaluation of the restoration } \\
\text { clinically }\end{array}$ & Weak \\
\hline $\begin{array}{l}\text { Liu \& Ma } \\
2008^{27}\end{array}$ & Prospective & China & $21-67$ & $\begin{array}{l}32 \text { males } \\
24 \text { females } \\
\text { Setting Not } \\
\text { reported }\end{array}$ & not reported & Up to 5 yrs & $\begin{array}{l}\text { Adapted USPHS } \\
\text { - } \quad \text { Secondary caries } \\
\text { - } \quad \text { Marginal seal } \\
\text { - } \quad \text { Gingivitis } \\
\text { - } \quad \text { Mood impaction } \\
\text { - } \quad \text { loose crowns }\end{array}$ & Weak \\
\hline
\end{tabular}




\begin{tabular}{|c|c|c|c|c|c|c|c|c|}
\hline $\begin{array}{l}\text { Roggend } \\
\text { orf et al } \\
2012^{28}\end{array}$ & Prospective & $\begin{array}{l}\text { Germ } \\
\text { any }\end{array}$ & $18-77$ & $\begin{array}{l}78 \\
\text { restorations } \\
\text { in } 35 \text { patients } \\
\text { University } \\
\text { setting }\end{array}$ & Single operator & $\begin{array}{l}7 \text { years } \\
\text { Average time period- } \\
84 \mathrm{mths}+/-6 \text { months of } \\
\text { clinical service }\end{array}$ & $\begin{array}{l}\text { - } \quad \text { Secondary caries } \\
\text { - } \quad \text { Vertical root fracture } \\
\text { Modified USPHS criteria } \\
\text { used for evaluation of the } \\
\text { restoration clinically }\end{array}$ & Weak \\
\hline $\begin{array}{l}\text { Ozyoney } \\
\text { et al } \\
2013^{29}\end{array}$ & Prospective & $\begin{array}{l}\text { Turke } \\
\text { y }\end{array}$ & $\begin{array}{l}\text { Mean age } 28.3 \\
\text { Age range : } 16-35\end{array}$ & $\begin{array}{l}53 \text { ETT in } 53 \\
\text { patients } \\
\text { University } \\
\text { setting }\end{array}$ & $\begin{array}{l}\text { Placed and } \\
\text { supervised by two } \\
\text { of the authors }\end{array}$ & 4 years & $\begin{array}{ll}\text { - } & \text { Debonds } \\
\text { - } & \text { Fracture of restoration } \\
\text { - } & \text { secondary caries } \\
\text { - } & \text { Modified USPilure/pain } \\
& \text { used for evaluation of the } \\
& \text { restoration clinically }\end{array}$ & Moderate \\
\hline $\begin{array}{l}\text { Otto and } \\
\text { Morman } \\
\text { n } 2015^{23}\end{array}$ & Prospective & $\begin{array}{l}\text { Switze } \\
\text { rland }\end{array}$ & $\begin{array}{l}\text { Mean age- } 53 \\
\text { Range- 25-79 }\end{array}$ & $\begin{array}{l}25 \\
\text { Endocrowns } \\
\text { and } 40 \\
\text { shoulder } \\
\text { crowns in } 55 \\
\text { patients } \\
\text { Private } \\
\text { practice } \\
\text { setting }\end{array}$ & $\begin{array}{l}\text { Single operator } \\
\text { Private practice } \\
\text { setting }\end{array}$ & $\begin{array}{l}\text { Mean clinical service at } \\
\text { follow-up-=10years and } 8 \\
\text { months } \\
\text { Range: } 9 \text { years and } 1 \text { month } \\
\text { up to } 12 \text { years and } 2 \text { months }\end{array}$ & $\begin{array}{l}\text { - } \text { Debonds } \\
\text { - } \quad \text { Fracture of restoration } \\
\text { Modified USPHS criteria } \\
\text { used for evaluation of the } \\
\text { restoration clinically }\end{array}$ & Weak \\
\hline
\end{tabular}




\begin{tabular}{|c|c|c|c|c|c|c|c|c|}
\hline $\begin{array}{l}\text { Botto et } \\
\text { al } 2016^{25}\end{array}$ & $\begin{array}{l}\text { Retrospecti } \\
\text { ve }\end{array}$ & $\begin{array}{l}\text { Urugu } \\
\text { ay }\end{array}$ & $\begin{array}{l}\text { Mean age: } 52 \text { years } \\
\& 8 \text { months in } \\
\text { Women (range- } 27- \\
75) \\
67 \text { years in men } \\
(65-69)\end{array}$ & $\begin{array}{l}11 \text { patients } \\
\text { Private } \\
\text { dental } \\
\text { practice }\end{array}$ & $\begin{array}{l}\text { Private dental } \\
\text { practice } \\
\text { Single operator }\end{array}$ & $\begin{array}{l}\text { Average follow-up- } \\
8 \text { years } 5 \text { months }-19 \text { years }\end{array}$ & $\begin{array}{ll}\text { - } & \text { secondary caries } \\
\text { - } & \text { radiographic failures } \\
\text { - } & \text { Marginal adaptation } \\
\text { - } & \text { Marginal discoloration } \\
& \text { Surface }\end{array}$ & Weak \\
\hline $\begin{array}{l}\text { Belleflam } \\
\text { me et al } \\
2017^{30}\end{array}$ & $\begin{array}{l}\text { Retrospecti } \\
\text { ve }\end{array}$ & $\begin{array}{l}\text { Belgiu } \\
\mathrm{m}\end{array}$ & $\begin{array}{l}55.2+/ \_12.6 \\
29 \text { to } 84\end{array}$ & $\begin{array}{l}64 \text { patients } \\
\text { University } \\
\text { setting }\end{array}$ & $\begin{array}{l}4 \text { Experienced } \\
\text { practitioner or pre- } \\
\text { graduated students }\end{array}$ & $\begin{array}{l}\text { Mean observation period } \\
44.7+/-34.6 \text { months } \\
\text { From July } 2004 \text { to July } 2015\end{array}$ & $\begin{array}{l}\text { - } \text { Debond } \\
\text { - } \text { major Fracture } \\
\text { - } \text { minor chipping } \\
\text { - } \quad \text { Caries } \\
\text { - } \text { Periodontitis } \\
\text { - } \quad \text { Rarginal adaptation } \\
\text { - }\end{array}$ & Weak \\
\hline $\begin{array}{l}\text { Fages et } \\
\text { al } 2017^{24}\end{array}$ & Prospective & France & $\begin{array}{l}\text { Age was not a } \\
\text { selection criteria (as } \\
\text { per information } \\
\text { from author's } \\
\text { email) }\end{array}$ & $\begin{array}{l}323 \text { patients } \\
\text { Private } \\
\text { Dental } \\
\text { Practice }\end{array}$ & $\begin{array}{l}\text { Same operator } \\
\text { Private Dental } \\
\text { Practice }\end{array}$ & $\begin{array}{l}\text { Treatment carried out } \\
\text { between 2003-2008 } \\
\text { up to } 7 \text { yrs, The last patient } \\
\text { follow-up occurred in } 2015 \text {. }\end{array}$ & $\begin{array}{l}\text { - } \text { Loss of restoration } \\
\text { - Partial/total tooth or } \\
\text { ceramic fracture } \\
\text { - Caries } \\
\text { - Endodontic complications }\end{array}$ & Weak \\
\hline
\end{tabular}


Table 2: Summary of Clinical Technique

\begin{tabular}{|c|c|c|c|c|c|c|c|}
\hline Study & Amount of Tooth structure & $\begin{array}{c}\text { Presence of adjacent teeth, } \\
\text { Abutment of FPD/RPD, Clinical/ } \\
\text { Occlusal assessment/ } \\
\text { Parafunctional habit }\end{array}$ & Tooth preparation & Endocrown material & Luting cement & $\begin{array}{l}\text { No of } \\
\text { molars } \\
\text { and } \\
\text { premolars } \\
\text { with } \\
\text { Interventi } \\
\text { on }\end{array}$ & $\begin{array}{c}\text { No of } \\
\text { molars/premola } \\
\text { rs dropouts }\end{array}$ \\
\hline $\begin{array}{l}\text { Bindl et al. } \\
2005^{19}\end{array}$ & $\begin{array}{l}\text { ETT with complete loss of the } \\
\text { clinical crown }\end{array}$ & $\begin{array}{l}\text { Static and dynamic occlusal } \\
\text { relationship were assessed prior } \\
\& \text { after procedure } \\
\text { Para functional habits not } \\
\text { recorded } \\
\text { Endodontic examination not } \\
\text { recorded. }\end{array}$ & $\begin{array}{l}\text { Preparation criteria } \\
\text { not mentioned }\end{array}$ & $\begin{array}{l}\text { Feldspathic block } \\
\text { ceramics ( Vitablocs } \\
\text { Mk II, Vita) }\end{array}$ & $\begin{array}{l}\text { resin based } \\
\text { posterior composite } \\
\text {-Tetric, Ivoclar } \\
\text { vivadent } \\
\text { light cured }\end{array}$ & $\begin{array}{l}\text { M-70 } \\
\text { PM- } 16\end{array}$ & $\begin{array}{l}\text { No drop outs } \\
100 \% \text { follow-up }\end{array}$ \\
\hline $\begin{array}{l}\text { Liu \& Ma } \\
2008^{27}\end{array}$ & $\begin{array}{l}\text { Extensive crown defects, with } \\
\text { some mesial or distal defects at } \\
\text { the gingival level } \\
\text { Severe tooth wear } \\
\text { Short clinical crown or supra } \\
\text { erupted opposing tooth. }\end{array}$ & Not reported & $\begin{array}{l}\text { Pulp chamber was } \\
\text { prepared in a box } \\
\text { shape }\end{array}$ & $\begin{array}{l}\text { Gold cast crown -12 } \\
\text { Platinum cast crown- } \\
33 \\
\text { Nickel Chromium }\end{array}$ & $\begin{array}{l}\text { Luted with GC Fuji I- } \\
\text { self cured }\end{array}$ & M- 61 & 1 drop out \\
\hline
\end{tabular}




\begin{tabular}{|c|c|c|c|c|c|c|c|}
\hline & & & & alloy- 16 & & & \\
\hline $\begin{array}{l}\text { Roggendorf } \\
\text { et al } 2012^{28}\end{array}$ & $\begin{array}{l}\text { The clinical crown was } \\
\text { completely destroyed, the pulp } \\
\text { chamber was used for additional } \\
\text { macro-mechanical retention }\end{array}$ & Not reported & $\begin{array}{l}\text { Preparation margins } \\
\text { not mentioned }\end{array}$ & $\begin{array}{l}\text { Vitablocks Mark II for } \\
\text { cerec or ProCAD }\end{array}$ & $\begin{array}{l}\text { Dual curing } \\
\text { Variolink }\end{array}$ & M-12 & 1 drop out \\
\hline $\begin{array}{l}\text { Ozyoney et } \\
\text { al } 2013^{29}\end{array}$ & $\begin{array}{l}\text { Extensive hard tissue loss with } \\
\text { thin cusps in mesiodistal/bucco } \\
\text { lingual directions with no dentin } \\
\text { support. }\end{array}$ & $\begin{array}{l}\text { No history of parafunction, no } \\
\text { removable partial dentures. } \\
\text { Endodontic assessment carried } \\
\text { out and retreatment carried out } \\
\text { as required. }\end{array}$ & $\begin{array}{l}\text { Preparation margins } \\
\text { not mentioned }\end{array}$ & $\begin{array}{l}\text { IPS Empress II } \\
\text { ceramic }\end{array}$ & $\begin{array}{l}\text { highly viscous and } \\
\text { dual cured luting } \\
\text { composite (Bifix } \\
\text { QM voco) }\end{array}$ & $M-53$ & $\begin{array}{l}\text { (3 lost to } \\
\text { follow-up) } 6 \% \\
\text { lost to follow- } \\
\text { up }\end{array}$ \\
\hline $\begin{array}{l}\text { Otto and } \\
\text { Mormann } \\
2015^{23}\end{array}$ & $\begin{array}{l}\text { Moderate to severe tooth } \\
\text { structure loss as per clinical } \\
\text { picture of typical preparation* }\end{array}$ & $\begin{array}{l}\text { Occlusion examined following } \\
\text { the fit }\end{array}$ & $\begin{array}{l}\text { Residual supragingival } \\
\text { thin walls were } \\
\text { shortens to } \\
\text { epigingival level and } \\
12 \% \text { taper to pulp } \\
\text { chamber retention } \\
\text { space }\end{array}$ & $\begin{array}{l}\text { Cerec Vitablocs Mark } \\
\text { II }\end{array}$ & $\begin{array}{l}\text { Dual composite } \\
\text { luting agent- Duo } \\
\text { Cement plus, } \\
\text { Coltene }\end{array}$ & $\begin{array}{l}\text { M- } 20 \\
\text { PM- } 5\end{array}$ & $100 \%$ follow- up \\
\hline $\begin{array}{l}\text { Botto et al } \\
2016^{25}\end{array}$ & $\begin{array}{l}\text { Amount of tooth structure : } \\
\text { moderate to severe tooth } \\
\text { structure loss* }\end{array}$ & $\begin{array}{l}\text { Pre-op } \\
\text { Endodontic Examination and } \\
\text { radiographs not reported } \\
\text { Occlusal Assessment carried out } \\
\text { Parafunctional habits checked }\end{array}$ & $\begin{array}{l}\text { Preparation margin- } \\
\text { Chamfer and butt } \\
\text { joint * }\end{array}$ & $\begin{array}{l}\text { IPS Empress-7 } \\
\text { Gold alloy-1 } \\
\text { Indirect comp-1 }\end{array}$ & $\begin{array}{l}\text { Bonded using dual } \\
\text { cure cement }\end{array}$ & $\begin{array}{l}\text { M- } 9 \\
\text { PM- } 2\end{array}$ & $100 \%$ follow-up \\
\hline
\end{tabular}




\begin{tabular}{|c|c|c|c|c|c|c|c|}
\hline & & but not reported & & & & & \\
\hline $\begin{array}{l}\text { Belleflamm } \\
\text { e et al } \\
2017^{30}\end{array}$ & $\begin{array}{l}\text { Level of damage to residual } \\
\text { tooth structure was classified 1- } \\
\text { 3- diagrammatic representation } \\
\text { in the article } \\
\text { CI I-16 } \\
\text { CI II-8 } \\
\text { CL III-76 }\end{array}$ & $\begin{array}{l}\text { Endodontic evaluation with pre- } \\
\text { op radiographs was under taken } \\
\text { and retreatment before } \\
\text { procedure was recorded } \\
\text { Occlusal relationship, presence } \\
\text { of parafunctional habits were } \\
\text { recorded } \\
\text { Recorded- } 1 \text { failed restoration to } \\
\text { be abutment of a partial denture }\end{array}$ & $\begin{array}{l}\text { presence of a buccal } \\
\text { chamfer / extension } \\
\text { into the pulp } \\
\text { chamber space }\end{array}$ & $\begin{array}{l}\text { Lithium Disilicate } \\
\text { glass-ceramic - } 84 \\
\text { PICN (Enamic Vita)- } \\
12 \\
\text { Artisanal Indirect } \\
\text { composite- } 3\end{array}$ & $\begin{array}{l}\text { Bonded with- } \\
\text { Variolink } 2 \text { (Ivoclar)- } \\
\text { dual cure }\end{array}$ & $\begin{array}{l}\text { M-56 } \\
\text { PM--41 }\end{array}$ & $100 \%$ follow-up \\
\hline $\begin{array}{l}\text { Fages et al } \\
2017^{24}\end{array}$ & $\begin{array}{l}\text { The endocrown / crown } \\
\text { selection criteria depended on } \\
\text { the amount of residual tooth } \\
\text { structure: } \\
\text { For endocrown: no limits under } \\
\text { the gingiva prohibiting a good } \\
\text { bonding, a residual surface of } \\
\text { enamel ensuring a good bonding } \\
\text { ( } 70 \% \text { minimum on the cervical } \\
\text { limit)* }\end{array}$ & $\begin{array}{l}\text { Endodontic Examination and } \\
\text { radiographs not reported for } \\
\text { assessment. } \\
\text { Exclusion criteria included } \\
\text { parafunctional habits, bruxism, } \\
\text { psychological disorders. }\end{array}$ & $\begin{array}{l}\text { Cervical butt margin } \\
\text { with a reduction of at } \\
\text { least } 2 \mathrm{~mm} \text { in the axial } \\
\text { direction. Pulp } \\
\text { chamber was } \\
\text { tapered, walls less } \\
\text { than } 2 \mathrm{~mm} \text { thickness } \\
\text { removed. }\end{array}$ & $\begin{array}{l}\text { CAD CAM } \\
\text { Vita Mark II ceramic } \\
\text { blocks were used }\end{array}$ & $\begin{array}{l}\text { Bonded usind Rely } \\
\text { X Unicem (Self } \\
\text { adhesive Cement) } \\
\text { 3M }\end{array}$ & M- 235 & $100 \%$ follow-up \\
\hline
\end{tabular}

\section{$M=$ molars}

\section{$\mathrm{PM}=$ premolars}

\section{* = Information obtained from personal communication with the authors}


Table 3: Summary of findings split into studies on molar endocrown and premolar endocrown- Legend: $M=$ molars, $\mathrm{PM}=$ premolars

\begin{tabular}{|c|c|c|c|c|c|c|c|}
\hline Study & $\begin{array}{l}\text { Type of teeth } \\
\text { M=molars } \\
\text { PM=premolars }\end{array}$ & $\begin{array}{l}\text { No of } \\
\text { premolars } \\
\text { /molars with } \\
\text { endocrown }\end{array}$ & Follow up period & No of failures & Reason for failure & Failure rate & Success rate \\
\hline $\begin{array}{l}\text { Bindl et al. } \\
2005^{19}\end{array}$ & PM & 16 & $\begin{array}{l}3 \text { years or more service time up } \\
\text { to } 7 \text { years } \\
\text { Mean time } 52+/-15 \text { months }\end{array}$ & 5 failures & - 5 adhesive failure/debond & $5 / 16=31.25 \%$ & $\begin{array}{l}11 / 16= \\
68.75 \%\end{array}$ \\
\hline $\begin{array}{l}\text { Bindl et al. } \\
2005^{19}\end{array}$ & M & 70 & $\begin{array}{l}3 \text { years or more service time up } \\
\text { to } 7 \text { years } \\
\text { Mean time } 52+/-15 \text { months }\end{array}$ & 14 failures & $\begin{array}{l}\text { - } 9 \text { molars had adhesive failure } \\
\text { - } 2 \text { vertical root fractures in } \\
\text { molar endo preparation } \\
\text { - } \quad 2 \text { failed due to periodontitis } \\
\text { - } 1 \text { failed due to inter-radicular } \\
\text { osteitis }\end{array}$ & $14 / 70=20 \%$ & $\begin{array}{l}56 / 70 \\
80.00 \%\end{array}$ \\
\hline $\begin{array}{l}\text { Liu \& Ma } \\
2008^{27}\end{array}$ & M & 61 & Up to 5 years & 2 failures & $\begin{array}{l}\text { - } 1 \text { secondary caries } \\
\text { - } 1 \text { mobility } \\
\text { - No loose or debond crowns }\end{array}$ & $2 / 60=3.33 \%$ & $\begin{array}{l}58 / 60= \\
96.67 \%\end{array}$ \\
\hline
\end{tabular}




\begin{tabular}{|c|c|c|c|c|c|c|c|}
\hline $\begin{array}{l}\text { Roggendorf } \\
\text { et al } 2012^{28}\end{array}$ & $\mathrm{M}$ & 12 & $\begin{array}{l}7 \text { years } \\
\text { Average time period- } 84 \\
\text { months }+--6 \text { months of clinical } \\
\text { service }\end{array}$ & 3 failures & $\begin{array}{l}\text { - } 2 \text { vertical root fracture } \\
\text { - } 1 \text { caries extracted }\end{array}$ & $3 / 11=27.27 \%$ & $8 / 11=72.73 \%$ \\
\hline $\begin{array}{l}\text { Ozyoney et al } \\
2013^{29}\end{array}$ & M & 53 & 4 years & 4 failures & $\begin{array}{l}\text { - } 1 \text { debond at } 1 \text { year re- } \\
\text { cemented and was } \\
\text { successful at } 4 \text { year recall } \\
\text { - } 1 \text { fracture + debond at } 3.3 \\
\text { year recall treated by post } \\
\text { and full crown } \\
1 \text { endo failure extracted in } 3 \\
\text { years } \\
1 \text { secondary caries + fracture } \\
\text { at } 4 \text { year recall -treated by } \\
\text { full ceramic crown }\end{array}$ & $4 / 50=8 \%$ & $\begin{array}{l}46 / 50= \\
92.00 \%\end{array}$ \\
\hline $\begin{array}{l}\text { Otto and } \\
\text { Mormann } \\
2015^{23}\end{array}$ & PM & 5 & $\begin{array}{l}\text { Mean clinical service at follow } \\
\text { up-=10yrs and } 8 \text { months } \\
\text { Range: } 9 \text { years and } 1 \text { month up to } \\
12 \text { years and } 2 \text { months }\end{array}$ & 1 failure & $\begin{array}{l}\text { - } 1 \text { Ceramic bulk fracture @ } 6 \\
\text { years and } 7 \text { months managed } \\
\text { with new Zirconia crown- } \\
\text { premolar }\end{array}$ & $1 / 5=20 \%$ & $4 / 5=80 \%$ \\
\hline $\begin{array}{l}\text { Otto and } \\
\text { Mormann } \\
2015^{23}\end{array}$ & M & 20 & $\begin{array}{l}\text { Mean clinical service at follow } \\
\text { up-=10 years and } 8 \text { months } \\
\text { Range: } 9 \text { years and } 1 \text { month up to } \\
12 \text { years and } 2 \text { months }\end{array}$ & 2 failure & $\begin{array}{l}2 \text { debonds - Both were } \\
\text { managed with new } \\
\text { endocrown }\end{array}$ & $2 / 20=10 \%$ & $\begin{array}{l}18 / 20= \\
90.00 \%\end{array}$ \\
\hline $\begin{array}{l}\text { Botto et al } \\
2016^{25}\end{array}$ & PM & 2 & $\begin{array}{l}\text { Average follow up- } 8 \text { years } 5 \\
\text { months }-19 \text { years }\end{array}$ & No failure & No failure & $0 / 2=0$ & $2 / 2=100 \%$ \\
\hline
\end{tabular}




\begin{tabular}{|c|c|c|c|c|c|c|c|}
\hline $\begin{array}{l}\text { Botto et al } \\
2016^{25}\end{array}$ & M & 9 & $\begin{array}{l}\text { Average follow-up } \\
8 \text { years } 5 \text { months }-19 \text { yrs }\end{array}$ & 1 failure & $\begin{array}{l}\text { - lost due to periodontal } \\
\text { involvement after } 12 \text { years \& } \\
9 \text { months }\end{array}$ & $1 / 9=11.11 \%$ & $8 / 9=88.89 \%$ \\
\hline $\begin{array}{l}\text { Belleflamme } \\
2017^{30}\end{array}$ & PM & 41 & $\begin{array}{l}\text { Mean observation period } 44.7+/- \\
34.6 \text { months } \\
\text { From July } 2004 \text { to July } 2015\end{array}$ & 1 failure & - 1 premolar failure (fracture) & $1 / 41=2.44 \%$ & $\begin{array}{l}40 / 41= \\
97.56 \%\end{array}$ \\
\hline $\begin{array}{l}\text { Belleflamme } \\
2017^{30}\end{array}$ & M & 56 & $\begin{array}{l}44.7+/-34.6 \text { months } \\
\text { From July } 2004 \text { to July } 2015\end{array}$ & 9 failures & $\begin{array}{ll}\text { - } & \text { Debond-2 } \\
\text { - } & \text { Fracture-2 } \\
\text { - } & \text { Caries-2 } \\
\text { - } & \text { Periodontitis-3 }\end{array}$ & $9 / 56=16.07 \%$ & $\begin{array}{l}47 / 56= \\
83.93 \%\end{array}$ \\
\hline $\begin{array}{l}\text { Fages et al } \\
2017^{24}\end{array}$ & M & 235 & $\begin{array}{l}\text { Treatment carried out between } \\
2003-2008 \\
\text { up to } 7 \text { yrs, The last patient } \\
\text { follow up occurred in } 2015 \text {. }\end{array}$ & 1 failure & $\begin{array}{l}\text { - } \quad \text { fracture appeared } 3 \text { months } \\
\text { after placement } \\
\text { - (Failed endocrown was a } \\
\text { third molar ) }\end{array}$ & $1 / 235=0.43 \%$ & $\begin{array}{l}234 / 235= \\
99.57 \%\end{array}$ \\
\hline
\end{tabular}

